\title{
The Development of POPSCRA Book Learning Media Based on Mnemonic Strategies on Measurement Materials to Improve Student Learning in Grade 4 SDN Sumberkembar Mojokerto
}

\author{
Nuril Nuzulia ${ }^{1, *}$ Vivy Endang Try Santi ${ }^{2}$ \\ ${ }^{1,2}$ UIN Maulama Malik Ibrahim Malang, Indonesia \\ *Corresponding author.Email: nuril.nuzulia@uin-malang.ac.id
}

\begin{abstract}
Popscra book learning media based on mnemonics can be used in mathematics learning because it stimulates students' skills in remembering sequence units of length and weight. The research method used Research and Development. Researchers adapted Borg and Gall's modified development model. The researcher only applies seven steps of development research. Results showed that the validation of media obtained a percentage of $80 \%$, $85 \%$, and $86 \%$, of the three experts of media, the media in a good category. The level of media attractiveness from the results of student questionnaires has a percentage level of $87 \%$. Difference student learning outcomes based on sample t-test independent shows $\mathrm{H}_{1}$ is accepted. Because $t_{\text {count }} 4.033>t_{\text {table }} 2.100$ with the acquisition of a post-test score of the experimental class 85.5, control class 77. So the conclusion that the use of mnemonic-based popscra book media is effective, and valid for application in grade 4 SDN Sumberkembar.
\end{abstract}

Keywords: POPSCRA Book Media, Measurement Materials, Student Learning Outcomes

\section{INTRODUCTION}

Education is generally seen as a concept that needs to be instilled in children from an early age. In the Act the national education system No. 20 of 2003 Article 3 states that 'the purpose of education to develop students' potential to become a man of faith and fear of God Almighty, noble, healthy, knowledgeable, skilled, creative, independent, and be citizens of a democratic and responsible" [1]. The educational goals can be achieved through a learning process in schools. This learning has a diverse scope, one of them is the learning of mathematics.

Learning mathematics is one of the lessons learned by students ranging from primary school level to college [2]. Therefore, mathematics is seen as exact subjects that play an important role in various fields to cultivate students' thinking correctly. It has been proved by research that shows Rasiman the result that a series of learning activities that emphasize problem-solving in mathematics can improve students' ability to think critically, analytically, systematically and logically [3]. This result was also confirmed by Rosnawati research showing that mathematics will have an impact on the efficiency and automation of students' critical thinking skills [4]. Therefore, it is necessary to create an interesting learning enthusiastic students learn mathematics. One of them is through the study of mathematics through the effective use of media.

The medium of learning in education proved to play an active role to improve the motivation, knowledge and intellectual learners in the learning process. This is proved by research conducted by Abiy Riabethe and Budi Astuti, which showed that the effective use of media can increase students' motivation so that people can gain knowledge and insight under the purpose of learning. Once the importance of learning media in education, in line with fulfilling the needs of students, especially at the primary level are still in the stage of concrete operations [5].

It is based on a cognitive theory proposed by Piaget in Desmita's book [6]. In the concrete operational stage, students are able to think logically about concrete events and classify objects into different shapes. Therefore, one way to concretize the abstract mathematical concept that 
is by generating a learning media is directly linked to students' daily lives.

Based on observations conducted by researchers at the date of October 2, 2020, at SDN Sumberkembar, Mojokerto Regency, most of the available learning media are dominated by science lessons, while mathematics learning media, especially the material for measuring units of length and units of weight, do not exist. The teacher only uses textbooks.

It is strengthened through interviews with fourthgrade teacher Mr. Topo, S. Pd, he said that the average student concentration only occurred 10-15 minutes at the beginning of the lesson. Meanwhile, in the learning process, the teacher only uses school textbooks. The loss of media supplies in the learning process was also encouraged by the Covid-19 pandemic which required students to study at home which only relied on textbooks. So that in the learning process students feel increasingly bored and lazy to learn because of the absence of interesting media.

In the material for units of length and weight, there is a unit ladder that students need to memorize and understand. In the process of memorizing the teacher also found the problem of students who find difficulty in remembering the sequence of unit conversions. Besides, when the students sort these units often doing some mistakes. This difficulty is often the reason students given practice or unit conversion problems during the teaching and learning process. The fatal issue brought up at the next grade level.

Of the ten students in class V SDN Sumberkembar, Mojokerto by questions regarding the material relationships between units, seven of them are not able to answer material relationships between these units. The real number of students who experienced an error in converting the relationship between the unit such as converting units from $\mathrm{cm}$ to $\mathrm{km}$, pounds to $\mathrm{kg}$ or vice vers. The reality is that the answers given by students are only guesswork, but still wrong. So that the number of students who experience errors in converting the relationship between units shows that the absorption of material on the relationship between units is not meaningful in students' memories. Automatically learning of mathematics would be difficult to apply by students in everyday life. However, it can be resolved if the effective use of media in learning mathematics presented mainly on material relationships between units.

Researchers developed an interactive media that can be used by teachers to achieve the desired objectives, namely media " popscra book based on mnemonic units of length and weight ". Popscra book is a book that is used in the learning process, it can replace the unit ladder image according to learning needs. Popscra book media is packaged in the form of a mnemonic-based book with a similar concept to pop-up scraft book media. According to an observer as well as a professional figure in the field of paper engineering, Rubin in Febrianto's writing stated that a pop-up is an illustration in which when the page is opened, drawn, or lifted, a level will arise with a three-dimensional impression [7]. Meanwhile, the scraft book by Luciana comes from the word scraft, which means waste, but making a scraft book is not just sticking from scraft. The definition of a scraft book is the art of sticking a photo or image on a paper and decorating it into a creative work or media.

The effectiveness of the use such media is corroborated by research conducted by Sepy Saparina using mnemonic-based media pocket book that shows the significance of the impact on student learning outcomes [8]. Besides, research conducted by Jatu Pramesti also demonstrated the feasibility of the media that are pop-up to get a decent score by experts, with the results of the analysis of the field test to get an average of 4.31 with a very good category. It shows pop-up media development is eligible to apply in the learning process [9].

From this, the researchers saw that the mnemonicbased popscra book media has never been developed for material relations between units before. Therefore, the development of popscra book media believed that the creation of learning needs to be applied by national education goals. Thus, from the entire description above researchers will conduct in-depth research with the title "The Development of Popscra Book Learning Media Based on Mnemonic Strategies on Measurement Materials to Improve Student Learning in Grade 4 SDN Sumberkembar Mojokerto".

The formulation of the research problem includes: 1) How does the process of developing learning media popscra book mnemonic base on measurement material for fourth-grade at SDN Sumberkembar? 2) How is the attractiveness of learning media popscra book mnemonic based on measurement material for fourthgrade at SDN Sumberkembar? 3) How are student learning outcomes in the classroom use and not use media popscra book mnemonic based on measurement material for fourth-grade at SDN Sumberkembar?

\section{METHODS}

This type of research used in this study the methods of research and development or known as the Research and Development (R \& D). Research and development are the research methods used to produce a specific product and test the effectiveness of the product in accordance with Sugiyono's theory [10]. The researcher refers to the Borg and Gall development model, which has ten stages, namely 1) Research and Information Collecting, 2) Planning, 3) Develop Preliminary Form a 
Product, 4) Preliminary Field Testing, 5) Main Product Revision, 6) Main Field Testing, 7) Revision Products, 8) Operational Field Testing, 9) Final Product Revision, 10) Dissemination and Implementation.

Of the ten steps, the researcher only used seven steps. This means that researchers using these seven steps do not reach large-scale field tests, researchers limit them to conducting small-scale testing. So that in the sixth step the researcher only uses one school and 1 class which is divided into two groups as the location and research subject. Whereas for steps seven, eight, and ten, the researchers did not use it.

In measuring the validity, effectiveness, and efficiency of popscra book media, researchers conducted product validation tests on material experts, design experts, and learning experts. Furthermore, field trials using these products to fourth-grade students of SDN Sumberkembar, Mojokerto Regency. Popscra book learning media is said to be effective if the posttest learning outcomes of the experimental class are higher than the post-test results of the control class.

The types of data processed are quantitative data and qualitative data. Quantitative data is data obtained based on scoring results, namely in the form of a percentage of the results of questionnaires from experts (material, media, learning) as well as students, as well as student learning outcomes in the form of scoring (pre-test and post-test) conducted in class. Furthermore, qualitative data is data obtained based on the results of information through interviews, as well as validation in the form of a questionnaire containing criteria and suggestions for consideration of improvement from experts (material, design, and learning) and students.

Instrument data collection in this research is in the form of interview instruments, questionnaires, and learning outcomes acquisition tests. First, the interview instrument contains questions that are used to determine all kinds of learning and administrative activities regarding conditions and situations in school. Second, a questionnaire instrument in the form of a closed questionnaire in the form of a checklist with a Likert scale which is used to measure the validity and attractiveness of the media. The questionnaire instrument was given to experts (material experts, design experts, learning experts) and students. The third is the instrument for the test of student learning outcomes. The test sheets are in two forms, namely pretest and post-test which are given to the control class and the experimental class.

The analytical technique in research and development is a very important process. Data analysis is the process of processing and interpreting data with its function so that it has clear meaning and meaning according to the type of data collected in accordance with Wina Sanjaya's theory [11]. There are two data analyses used by researchers to process data in the research and development of this product, namely descriptive analysis, and t-test analysis. The technique is used by the data obtained from the data collection process.

Analysis of the results of questionnaires that have been distributed to a number of parties, to determine the feasibility of the mnemonic-based popscra book media, it will be calculated by the formula per group of points and the overall points according to the theory put forward by Nana Sudjana [12]

$$
P=\frac{\sum \mathrm{x}}{\sum \mathrm{x}} 100 \%
$$

$$
\begin{aligned}
& P=\text { The percentage of the level of validity } \\
& \sum \mathrm{x}=\text { Answer Rating Selected } \\
& \sum \mathrm{xi}=\text { Scores Answer Rating }
\end{aligned}
$$

Furthermore, the analysis of the learning outcomes test is used to determine the differences in the learning outcomes of the control class and the experimental class. To determine the significance of the differences between the control and experimental classes, it is necessary to test statistically with a correlated t-test. The formula proposed by Sugiyono used to calculate the ttest is:

$$
t=\frac{\bar{x}_{1}-\bar{x}_{2}}{\sqrt{\frac{\left(n_{1}-1\right) s_{1}^{2}+\left(n_{2}-1\right) s_{2}^{2}}{n_{1}+n_{2}-2} \cdot\left(\frac{1}{n_{1}}+\frac{1}{n_{2}}\right)}}
$$

$t \quad=\mathrm{t}$-test

$x_{1} \quad=$ average value of the experimental class

$x_{2} \quad=$ average value of the control class

$s_{1} \quad=$ variance of the experimental class sample

$s_{2} \quad=$ variance of the control class sample

$n_{1} \quad=$ number of experimental class respondents

$n_{2} \quad=$ number of control class respondent

\section{RESULT AND DISCUSSION}

This research and development produce a product teaching material is Popscra-Book based on mnemonics on unit length and weight for class IV, which aims to improve the learning outcomes of fourth-grade students of SDN Sumberkembar Mojokerto. The descriptions of the results of research and product development are as follows: 


\subsection{The Process of Developing Popscra Book Learning Media)}

The process of developing this popscra-book media refers to the theory of Borg and Gall's model. Based on the steps that have been adapted in the model, the researcher uses seven stages, namely: collecting data, planning, initial product development, initial product testing, product validation by the three experts followed by revisions, broad-scale trials, and final product revisions. The following are the results of product development as follows:

First, research and information. Based on observations, identification of the curriculum at SDN Sumberkembar, Mojokerto Regency. Researchers get data in the form of core competencies, basic competencies, indicators, and learning objectives. In addition, researchers also found problems in the learning process, especially in the material for units of length and weight, as teachers only use school textbooks. So that in the learning process students feel increasingly bored and lazy to learn because of the absence of interesting media. This was also supported when students sorted the units in measurement, they often reversed. This difficulty is often the reason when students are given exercises or unit conversion questions during the teaching and learning process.

Second, Planning. After collecting information by conducting observations and interviews, collecting related theories, a product-making plan is compiled. The product is a Mnemonic-based POPSCRA Book learning media used for learning units of length and weight for fourth-grade students of SDN Sumberkembar. For this reason, products are made according to the characteristics of grade IV primary school children.

Third, develop the preliminary from the product. At this stage, what is done is to make a product design, namely compiling the initial product of the POPSCRA learning media based on mnemonics. The media are arranged based on the goals and objectives that have been planned. The resulting media is structured as follows:

\subsubsection{Product Identification}

Table 3.1.1. Identity of Popscra Book Learning Media Based on Mnemonics

\begin{tabular}{|c|c|}
\hline Physical form & Print \\
\hline Book title & $\begin{array}{l}\text { Popscra book media based on } \\
\text { mnemonic units of length unit weight }\end{array}$ \\
\hline Target & $\begin{array}{l}\text { Grade IV student of SDN } \\
\text { Sumberkembar Mojokerto }\end{array}$ \\
\hline $\begin{array}{l}\text { Page } \\
\text { thickness }\end{array}$ & 7 pages \\
\hline Print & First \\
\hline Font size & $12,16,25$ \\
\hline Font type & $\begin{array}{l}\text { Geo Slab703 Md BT, Quotable, } \\
\text { Comic Sans MS, Headster }\end{array}$ \\
\hline $\begin{array}{l}\text { Page paper } \\
\text { size }\end{array}$ & $19 \mathrm{~cm} \times 16 \mathrm{~cm}$ \\
\hline Space & 1.5 \\
\hline $\begin{array}{l}\text { Media } \\
\text { section } \\
\text { components }\end{array}$ & $\begin{array}{l}\text { Front page, foreword, instructions for } \\
\text { use, material content (meaning, } \\
\text { mnemonic reminders in units of } \\
\text { length and weight, examples in daily } \\
\text { life, relationships between units, } \\
\text { pictures of unit ladders, unit } \\
\text { conversion tables, pictures of } \\
\text { measuring instruments for each } \\
\text { unit), questions evaluation, about the } \\
\text { author, back page }\end{array}$ \\
\hline
\end{tabular}

\subsubsection{Design Aspect}

\subsubsection{Book Cover}

The results of the front cover design in this media development use illustrations of pictures related to the media title. While the back cover contains a description of the contents of the book. In addition, motivational words from the author and supervisor for readers.

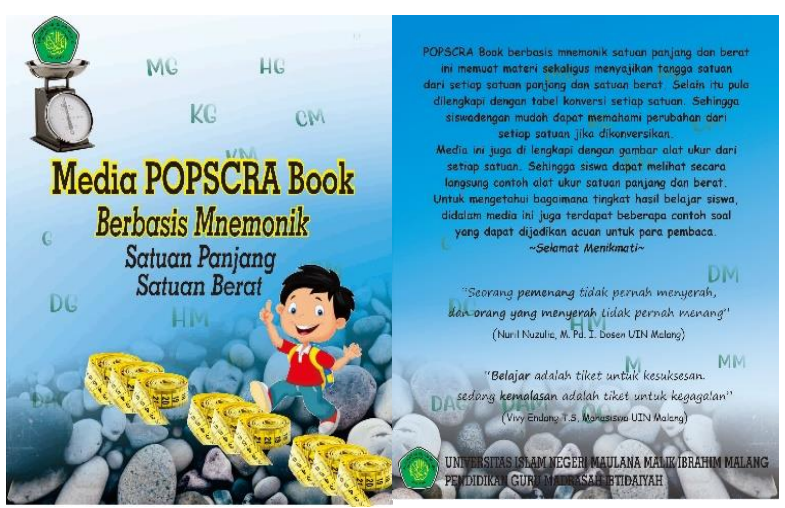

Figure 1. Front and Back Cover Design 


\subsubsection{Foreword section and instructions for use}

The foreword contains the opening of communication between the book and the reader. As well as the instructions for use, it contains directions for the reader when using this book.
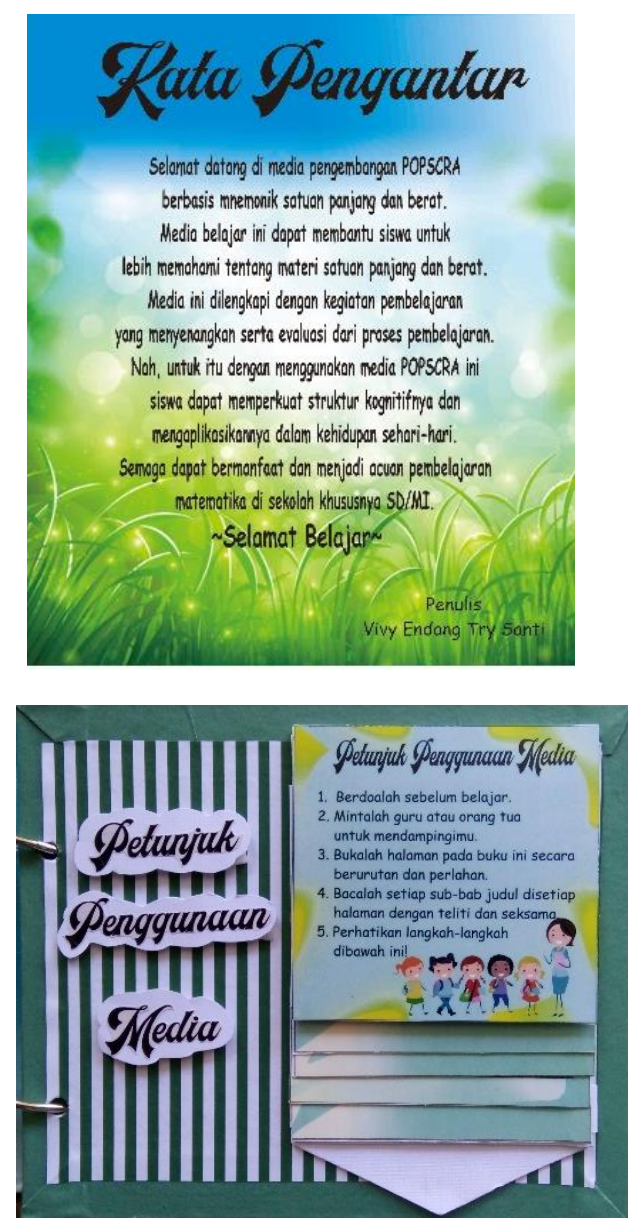

Figure 2. The Foreword

\subsubsection{Material section}

The content of the material contains 5 sub-chapters of the material in a sequence below, consisting of the notion of units of length and unit of weight, the relationship between units of weight, a reminder of units of length and weight, each sub-chapter of the material, is designed into one section that can be opened by pulling the paper by title whose purpose is to make it easier for students to read the material. As for the unit length and weight ladder, the length unit conversion table, the weight unit conversion table, the drawing unit length measurement tool, the unit weight measurement tool drawing, are designed according to the placement of each with different opening drawings and models.
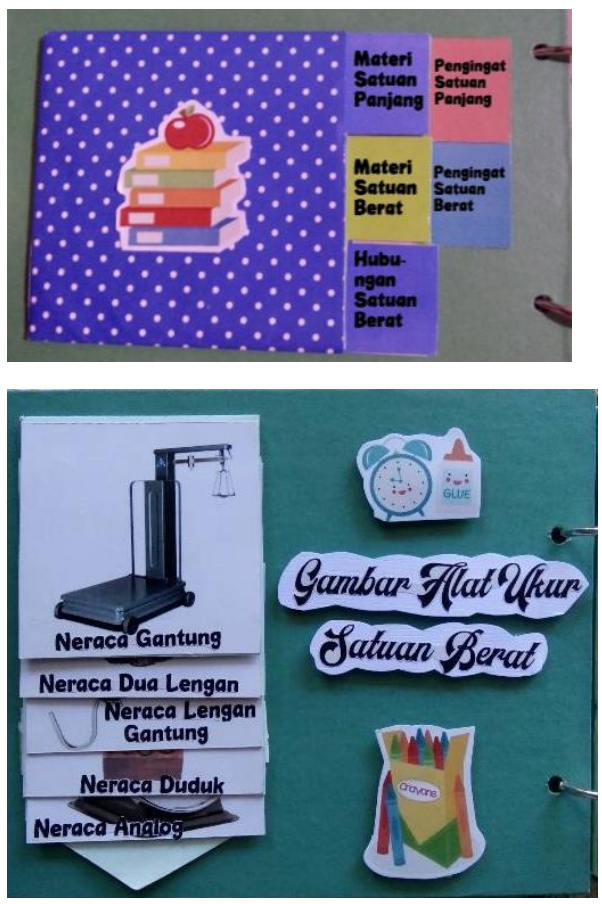

Figure 3. Material Section

\subsubsection{Evaluation section}

Contains practice questions in the form of stuffing and story questions. The purpose of the evaluation is to determine the level of students' understanding of units of length and weight.
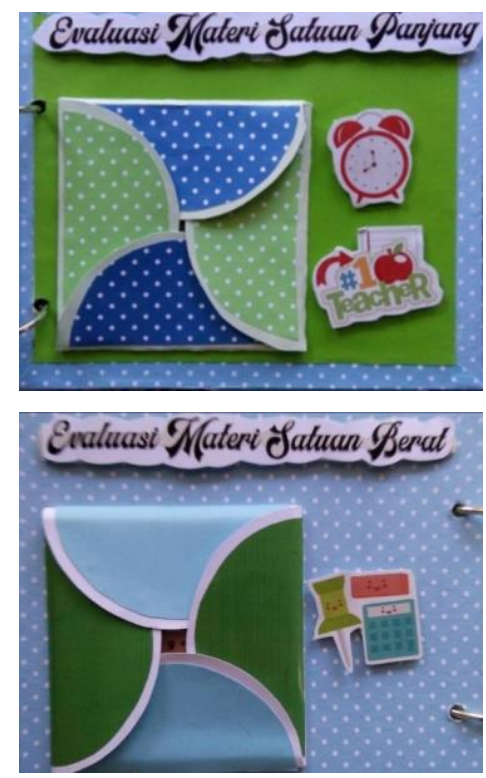

Figure 4. Evaluation Section

Fourth, preliminary field testing. The validation of content experts was carried out by FITK lecturer at UIN Maulana Malik Ibrahim Malang, Mrs. Ria Norfika Yuliandari, M. Pd. The results of the media content expert validation were quantitative data. The 
quantitative data got a percentage of $80 \%$. This figure is converted to the product eligibility criteria conversion table, the percentage of the achievement level of $80 \%$ is in good qualification. Validation on media design experts conducted by FITK lecturer at UIN Maulana Malik Ibrahim Malang, Mr. Galih Puji Mulyoto, M. Pd. Namely, in the form of quantitative data, the percentage calculation is $85.3 \%$. This figure is converted to the product eligibility criteria conversion table, the percentage of the achievement level of $85.3 \%$ is in good qualification. So there is no need for revision. Expert validation of learning conducted by homeroom teacher for grade IV SDN Sumberkembar Mojokerto, Mr. Topo, S. Pd. Namely in the form of quantitative data to get a percentage of $86 \%$. This figure is converted to the product eligibility criteria conversion table, the percentage of the achievement level of $86 \%$ is in good qualification. So there is no need for revision.

Fifth, main product revision. The results of the material validation conducted by FITK lecturer at UIN Maulana Malik Ibrahim Malang, Mrs. Ria Norfika Yuliandari, M. Pd, obtained qualitative data in the form of suggestions and criticisms, among others, the use of sentences and pronouns should be simpler and more engaging to the reader. Ananda becomes a student, in the evaluation questions include character values, light, and real positive content that exists in everyday life, as well as those that hone students' logic. For the results of the design expert validation conducted by the lecturer of FITK UIN Maulana Malik Ibrahim Malang, Mr. Galih Puji Mulyoto, M. Pd, obtained qualitative data in the form of suggestions and criticisms, among others, there need to be instructions for using the media. Answer keys and hot questions in writing size 16. Meanwhile, for the validation of learning experts, qualitative data is obtained in the form of suggestions and criticisms, among others, good learning media, helping teachers in learning. If using popscra book media for a large number of students, so that it is doubled or the size of the book, pictures and writings should be enlarged. Based on suggestions and criticisms from learning experts, researchers analyzed and did not make revisions to popscra-Book media.

Sixth, playing field testing. The field test was carried out on 10 grade IV SDN Sumberkembar students by giving pre-test sheets, providing treatment with the developed product and providing post-test questions. Then proceed with giving a questionnaire to assess the attractiveness of the mnemonic-based POPSCRA Book media.

Seventh, Final product Revision. In the field test of the final product, there is no need for revision from the media. The problem is only found during the learning process in the class layout which is not proportional so that there are still students who cannot see clearly when the teacher demonstrates the media. In this case, the teacher is expected to be able to overcome this problem by rearranging the layout of the student chairs.

\subsubsection{Result of The Poscra-Book Learning Media Interesting}

The level of attractiveness in popscra book learning media based on mnemonic units of length unit weight was determined by filling out a questionnaire conducted by fourth-grade students of SDN Sumberkembar, Sumbersuko Group or experimental class. Data analysis is calculated using the percentage formula as follows:

The percentage formula as follows:

$$
\begin{aligned}
& \mathrm{P}=\frac{\sum \mathrm{x}}{\sum \mathrm{xi}} 100 \% \\
& \mathrm{P}=\frac{209}{240} \quad \mathrm{X} 100 \% \\
& \mathrm{P}=87 \%
\end{aligned}
$$

The data above is quantitative data from the mnemonic-based POPSCRA Book field test. Based on the acquisition above the percentage is equal to $87 \%$. That matter shows that the theory put forward by Jamil Suprihatiningrum about the media says that the media which is used as an introduction or intermediary from the sender to the recipient who carries information or subject matter can stimulate thoughts, feelings, and willingness, which aims to make it easier to achieve learning objectives is valid and appropriate [13]. So, through the mnemonic-based POPSCRA Book media which is packaged in the form of a pop-scraft book, it can increase the attractiveness of the media which aims to provide convenience in the learning process.

\subsection{Differences in Learning Outcomes for Students Learn Using Popscra Book Media and Students Do Not Use Media}

After conducting field trials at SDN Sumberkembar Mojokerto, the average pre-test score in the experimental class was 54.5 , which was included in the failure criteria. Then the post-test average value in the experimental class is to get 85.5 which indicates good criteria. Meanwhile, the control class obtained the same pre-test results as the experimental class with an average score of 54.5 which indicates that the criterion failed. Furthermore, the post-test obtained by the control class got an average value of 72.5 . This shows that there is a difference between the mean value of the experimental class and the control class.

In the experimental class, they received more learning experiences, namely by using the popscra book media. The learning outcomes obtained were better than 
the control class. This strengthens the meaning of learning outcomes stated by Masnur Muslich that learning outcomes are the abilities that students have after receiving their learning experiences [14]. The students' abilities are in the form of cognitive abilities which are assessed through the post-test. The analysis was carried out through a significance test on student learning outcomes data. Manual t-test analysis showed the following results:

$$
\begin{aligned}
& \begin{array}{l}
t=\frac{85,5-72,5}{\sqrt{\frac{(10-1) 7.245688373^{2}+(10-1) 7.168604389^{2}}{10+10-2}}} \\
t=\frac{13}{\sqrt{\frac{(9) .7,245688373^{2}+(9) .7 .168604389^{2}}{18} \cdot\left(\frac{2}{10}\right)}}
\end{array} \\
& t=\frac{13}{\sqrt{\frac{(9) .52,499999999+(9) \cdot 51,388888886}{18} \cdot\left(\frac{2}{10}\right)}} \\
& 13 \\
& t=\frac{13}{\sqrt{\frac{472,49999999+462,49999997}{18} \cdot(0,2)}} \\
& t=\frac{13}{\sqrt{\frac{934,99999996}{18} \cdot(0,2)}} \\
& t=\frac{8,5}{\sqrt{51,944444442 \cdot 0,2}} \\
& t=\frac{13}{\sqrt{10,388888888}} \\
& t=\frac{13}{3,2231799342} \\
& t=4,0332839821 \\
& t=4,033
\end{aligned}
$$

a. Significance level of 0,05

$$
\text { b. } \begin{aligned}
\mathrm{dk} & =n_{1}+n_{2}-2 \\
& =10+10-2=18
\end{aligned}
$$

So that we get $t_{\text {table }}=2,100$

From the calculation of the $t_{\text {count }}$ above, the results will be compared with the t-table using a significance level of 0.05 or $5 \%$. The decision making is determined by the following conditions:

$\mathrm{H}_{0}=$ there is no significant difference between learning outcomes in the experimental class and the control class.

$\mathrm{H}_{1}=$ there is a significant difference between learning outcomes in the experimental class and the control class.

Test criteria, if: a. $\mathrm{T}_{\text {count }}>\mathrm{t}_{\text {table, }}$, then $\mathrm{H}_{0}$ is rejected. $\mathrm{H}_{1}$ is accepted, meaning that there is a significant difference in the mean between the two variables investigated.

b. $\mathrm{T}_{\text {count }}<\mathrm{t}_{\text {table }}$ then $\mathrm{H}_{0}$ is accepted. $\mathrm{H}_{1}$ is rejected, meaning that there is no significant difference in the mean between the two variables investigated.

Based on the results of the calculations and comparisons above, it can be seen that there is a significant difference between students who use Popscra book media and students who don't use Popscra book $\left(\frac{1}{10}+\frac{1}{10}\right)$

Some of the factors that make this media can improve student learning outcomes, one of which is the criteria for selecting media based on aspects including the suitability of objectives, the condition of students, the appropriateness of use, availability, teacher skills, and technical use, besides this media is also equipped with descriptions. Evaluation material and questions. The existence of pictures of measuring instruments for each unit arises according to the original picture, and the opening technique of each part of the material can help students remember the sequence of units of length and weight, sharpening the students' brains in understanding each sub-material. The presentation of story questions is packaged in the form of a story that has a relationship with students' daily lives.

\section{CONCLUSION}

Based on the research results that have been described in the previous chapter regarding the development of popscra book learning media based on mnemonics, unit length and weight unit material in grade IV SDN Sumberkembar Mojokerto can be concluded as follows:

The popscra book learning media specifications in this research and development include a cover. Foreword, instructions for use, material for units of length and weight (definition of units of length and unit of weight, relationships between units, reminders between units, unit ladders, conversion tables for each unit, pictures of measuring instruments for each unit), evaluation of learning from each unit, regarding the author, and finally the back page of the book which contains a brief content about the media and some motivational words. This media was tested on three validators, namely content experts, design experts, learning experts. The results of the evaluation by content experts obtained $80 \%$, the results of the design experts' assessment obtained a value of $85 \%$, and the results of the assessment by the learning experts obtained $86 \%$.

The attractiveness of the popscra book media based on the results of the fourth-grade students' assessment of SDN Sumberkembar Mojokerto obtained a score of $87 \%$. This shows that students are interested in the 
popscra book media. This media is considered attractive because it is presented in a simple form in the form of a book, which is equipped with pictures and techniques for opening each section that attracts students to learn and understand each material presented.

Based on the results of product trials conducted on the experimental class and the control class. Popscra book media developed by researchers can improve student learning outcomes, this can be seen from the results of the post-test. So that it is suitable for use in learning. The results of the t-test which was carried out manually using the formula and using SPSS showed that the average post-test score of the control class was 72.5 and the experimental class was 85.5. In making a decision, it can be seen from the significance if $t_{\text {count }}>$ $\mathrm{t}_{\text {table }}=4.033>2.100$ proves that it is very significant. This shows that popscra book media can improve student learning outcomes because the presentation of this media is interesting. Detailed material description with the opening technique of each interesting part of the material, accompanied by pictures of the measuring instrument for each unit, can help students remember the sequence of units of length and weight. So that students easily understand the questions and understand the relationship between units.

\section{REFERENCES}

[1] Undang-Undang Republik Indonesia Nomor 20 Tahun 2003 Tentang Sistem Pendidikan Nasional. 2003.

[2] C. Supatmono, Matematika Asyik. Jakarta: PTGramedia Widiasarana Indonesia, 2015.

[3] Rasiman, 'Meningkatkan Kemampuan Berpikir Kritis Melalui Pembelajaran Matematika dengan Pendekatan Matematika Realistik', Journal of Axiom, vol. 4, no. 2, 2013.

[4] R. Rosnawati, 'Berpikir Kritis melalui Pembelajaran Matematika untuk Mendukung Pembentukan Karakter Siswa', presented at the Papers Presented in National Seminar on Education, Sanata Dharma University Yogyakarta, 2012.
[5] A. Risabethe and B. Astuti, 'Pengembangan Media Pembelajaran untuk Meningkatkan Motivasi Belajar dan Karakter Semangat Kebangsaan Siswa Kelas V SD', Journal of Character Education, vol. 1, no. 7, 2017.

[6] D. Desmita, Psikologi Perkembangan. Bandung: Remaja Rosdakarya, 2013.

[7] M. F. Febrianto, 'Penerapan Media dalam Bentuk Pop-Up Book pada Pembelajaran Unsur-Unsur Rupa untuk Siswa Kelas 2 SDNU Kanjeng Sepuh', Journal of Art Education, vol. 2, no. 3, 2014.

[8] S. Saparina, 'Effectiveness Handbook Based Retention Mnemonics Against Students with SQ3R Method in Sub Material Bone in Class XI MAN 2 Pontianak', the Faculty of Education, University of Muhammadiyah, Pontianak, 2016.

[9] J. Pramesti, 'Pengembangan Media Pop-Up Book tema peristiwa untuk kelas III SD Negeri Pakem 1', The Faculty of Education State University of Yogyakarta, Yogyakarta, 2015.

[10] S. Sugiyono, Metode Penelitian Kuantitatif Kualitatif dan R \& D. Bandung: Alfabeta, 2010.

[11] W. Sanjaya, Penelitian Tindakan Kelas. Jakarta: Kencana Prenada Media Group, 2009.

[12] N. Sudjana, Penilaian Hasil Proses Belajar Mengajar. Bandung: Rosda Karya, 1990.

[13] J. Suprihatiningrum, Strategi Pembelajaran: Teori \& Aplikasi. Yogyakarta: Ar-Ruzz Media, 2017.

[14] M. Muslich, Penilaian Berbasis Kelas dan Kompetensi. Bandung: Redlika Aditama, 2011. 